\title{
THE ATMOSPHERIC CONDITIONS OF HOT AND MILD DESERTS TO BE GEOENGINEERED
}

Dr. Ugur Sevilmis

Eastern Mediterranean Agricultural Research Institute, Adana, Turkey

ugur.sevilmis@tarimorman.gov.tr

sevilmisugur@yahoo.com

\begin{abstract}
Excess evaporation due to hot, dry and sunny atmosphere with low precipitation and low water holding capacity in ground results with hot hyper arid zones in the world. Sahara, Australia and Arabian deserts are top three covering 9 billion, 2.7 billion and 2.3 billion ha respectively. This paper describes the current knowledge on general atmospheric circulations as a base to a theory to geoengineer the atmosphere to send the climate of Sahara back to 6.000 years ago where tropical grasslands were dominating.
\end{abstract}

Keywords: Desert, humidity, temperature, African Humid Period, geoengineering

\section{Introduction}

In a desert there is an excess evaporation over precipitation. Bald, rocky, or sandy surfaces also hold little moisture and helps to evaporate the low precipitation. Hot desert climate (BWh), and a cold desert climate (BWk) (according to Köppen climate classification) are two variations of a desert climate. Hot desert climates are found often between $20^{\circ}$ and $33^{\circ}$ latitudes. Hot deserts are generally sunny, hot and dry year-round where they can be found in North Africa (Sahara Desert, Libyan Desert Nubian Desert); in the Horn of Africa (Danakil Desert, Grand Bara Desert); in Southern Africa (Namib Desert and Kalahari Desert); in Middle East (Arabian Desert, Syrian Desert and Lut Desert); in South Asia (Dasht-e Kavir and Thar Desert) in North America (Mojave Desert, Sonoran Desert and Chihuahuan Desert); in Australia (Simpson Desert, Great Victoria Desert. World's biggest hot deserts are Sahara, Australia, Arabian, Kalahari, Syrian, Chihuahuan, Sonoran, Thar deserts which cover 9 million, 2.7 million, 2.3 million, 0.9 million, 0.5 million, 0.4 million 0.3 million and 0.2 millon $\mathrm{km}^{2}$, respectively. There, hot-month average temperatures are normally between 29 and $35^{\circ} \mathrm{C}$ dailiy averages with $43-46^{\circ} \mathrm{C}$ midday temperatures. During colder periods of the year, night-time temperatures can drop to freezing due to the extreme radiation loss under the clear skies. Hot deserts are hot, dry and sunny because of nearly constant high pressure, permanent removal of low pressure systems, dynamic fronts, dynamic atmospheric disturbances, sinking air motion, dry atmosphere near the surface, aloft, the exacerbated exposure to the sun and always high solar angles. Mild desert climates (BWn) are found along the coasts of continents 
at tropical or near tropical locations, or at high altitudes of hot deserts like Atacama Desert, Pacific coast of the Baja California Peninsula, coastal Namibia and Yemen. Cold ocean currents, frequent fog, low clouds, low precipitation, mild temperatures are typical in mild deserts. The consistently warm, dry, and sunny conditions of the horse latitudes are the main reason for the existence of the world's non-polar deserts, such as the Sahara Desert in Africa, the Arabian and Syrian deserts in the Middle East, the Mojave and Sonoran deserts in the southwestern United States and northern Mexico, all in the Northern Hemisphere; and the Atacama Desert, the Kalahari Desert, and the Australian Desert in the Southern Hemisphere. (Pan et al., 2016; Anonymus 1-7).

\section{Global Atmospheric Circulations}

The sun is the main heat source of earth's atmosphere. More sun energy reaches to the equatorial regions compared to the poles due to the curvature of the earth. More energy concentrates near the equator compared to poles. Tilt of the axis of earth also prevents polar regions recieve daylight during winter. Between poles and $40^{\circ}$ latitudes, the heat radiation outgoing to space from earth exceeds the incoming heat radiation. As a total result, a thermal gradient occurs between equator and poles. The atmosphere redistributes this energy imbalance by complex atmospheric circulations. If earth did not rotate and was a simple mass land with no oceans we would have a single circulatory cell in each hemsiphere where hot air would rise at the equator and flow to the poles. Then the air would sink as it cools there and then return to the equator. But this is not the case and due to the unequal distribution of oceans and lands and speed of earth's rotation. Instead these circulations happens in three cells both in northern and southern hemispheres. The largest circulation cells are Hadley Cells. They circulate the rising warmer and less dense air of equator to the poles. The air rises about $18 \mathrm{~km}$ at the equator to Tropopose and turn to poles underneath this layer. The Tropopose is the lowest layer of the atmospheric layers where all wheather conditions happen. On the way to the poles, the warm air slowly cools and sinks. On the $30^{\circ}$ latitudes, the cooled and sink air turns to equator close to surface of earth until it reaches to the $0^{\circ}$ latitude to recirculate. Circulation in the Hadley cells results with winds. The wind direction for close to the surface in Northern hemisphere is not exactly from North to South direction. Higher turning speed of equatorial latitude result with winds of South-West direction in Nothern hemisphere. In the Southern hemisphere, wind direction is from $30^{\circ}$ latitude to equator to the North-west direction. These two winds are named as Trade Winds. Between northern and southern Hadley Cells, there is an unwindy zone named Doldrums. The "doldrums" is a popular nautical term that refers to the belt around the Earth near the equator where sailing ships sometimes get stuck on windless waters. Doldrums, the Inter-Tropical Convergence Zone, (ITCZ, pronounced as "itch"), is a belt around five degrees of the equator. Here, the trade winds of the northern hemisphere blow to the southwest and collide with the northeast trade winds of southern hemisphere. Due to the upward air circulation, there is little surface wind in the ITCZ. The smallest atmospheric circulation cells are Polar Cells of Northern and Southern hemisphere. In these cells, cold, dense air close to the ground flows from poles to $60-70^{\circ}$ latitudes. On the way, air gets warm and rise where then 
return to the poles again at high elevations. Between Hadley and Polar Cells, there are Ferrel Cells. Unlike other cells, Farrel Cells are not driven by temperature. The circulation direction in here is decided by neighbouring cells. In the Hadley Cells, the sinking air forces the neighbouring Ferrel Cells to sink, too. In the polar cells, the rising air forces the neighbouring Ferrel Cells. All these circulating cells are transporting heat from equator to poles and creating high and low pressure zones. Also rising and descending parts of the circulation cells result with climatic zones. In areas where air is rising, there are low pressure, rainy zones. This is why the rain forests are found on the equator. In zones where air is descending, the high pressure result with clear sky and little rainfall which creates deserts. But all deserts are not hot. Antarctica in the polar cell is classified as a desert due to less rainfall it recieves than Sahara. The sinking air mass between Ferrel and Hadley Cells, at the latitudes known as the horse latitudes, where the air moves downward toward Earth's surface, there is insufficient wind for sail a ship was said to be 'horsed'. Horse latitudes (subtropical ridges or subtropical highs) are the subtropical latitudes between 30 and 35 degrees both North and South. There the Earth's atmosphere is dominated by the subtropical high pressure, which suppresses precipitation and cloud formation, and has variable winds mixed with calm winds. The term horse latitudes may originates from Spanish transported horses by ship often became becalmed in mid-ocean in this latitude. Severely prolonged voyage due to unwindy conditions, resulting water shortages forced crew to throw the dead or dying animals to sea. The hot land deserts of the world are between the belt of sinking air associated with the subtropical high-pressure systems. The deficit of water vapor and vegetation cover eliminates clouds to block the sun and evaporational cooling near the ground during the daytime, resulting with high afternoon temperatures. At night, the dry, frequently cloudless atmosphere transmits infrared energy through the atmosphere resulting with rapid cooling and high day/night temperature variations ((Anonymus 8-13) (Fig. 1). 


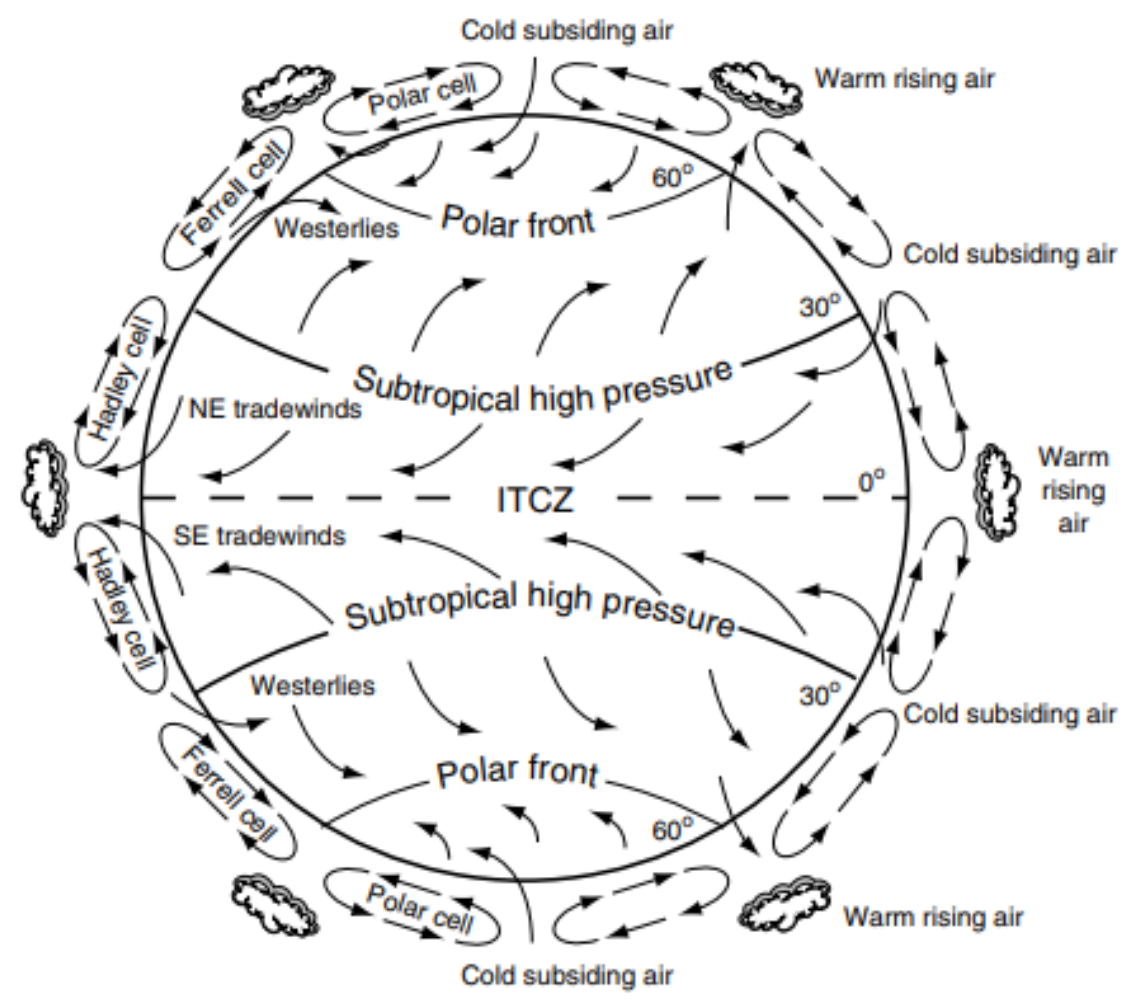

Figure 1. Atmospheric circulations of earth (Chapin et al., 2011).

\section{African Humid Period}

The Sahara, the world's largest hot desert, was once fertile grassland. From lakes and grasslands with hippos and giraffes to a vast desert, North Africa's sudden geographical transformation 5,000 years ago was one of the planet's most dramatic climate shifts. Humid Period's end was about 6,000 years ago (Anonymus, 14). There is great uncertainty over the timing and magnitude of the termination of the African Humid Period (AHP). AHP was a period of enhanced moisture over most of northern and eastern Africa. However, beginning 8000 years ago the moisture balance shifted due to changing orbital precession and vegetation feedbacks. Some records indicate a fast, while others indicate a more gradual change from wet to dry conditions. Although human agents are not seen as the only forces inducing regime change during the termination of the AHP, potential role of adoption of agriculture and pastoralism in northern Africa is argued to enhance devegetation and regime shifts in unbalanced ecosystems (Wright, 2017) (Fig. 2). 


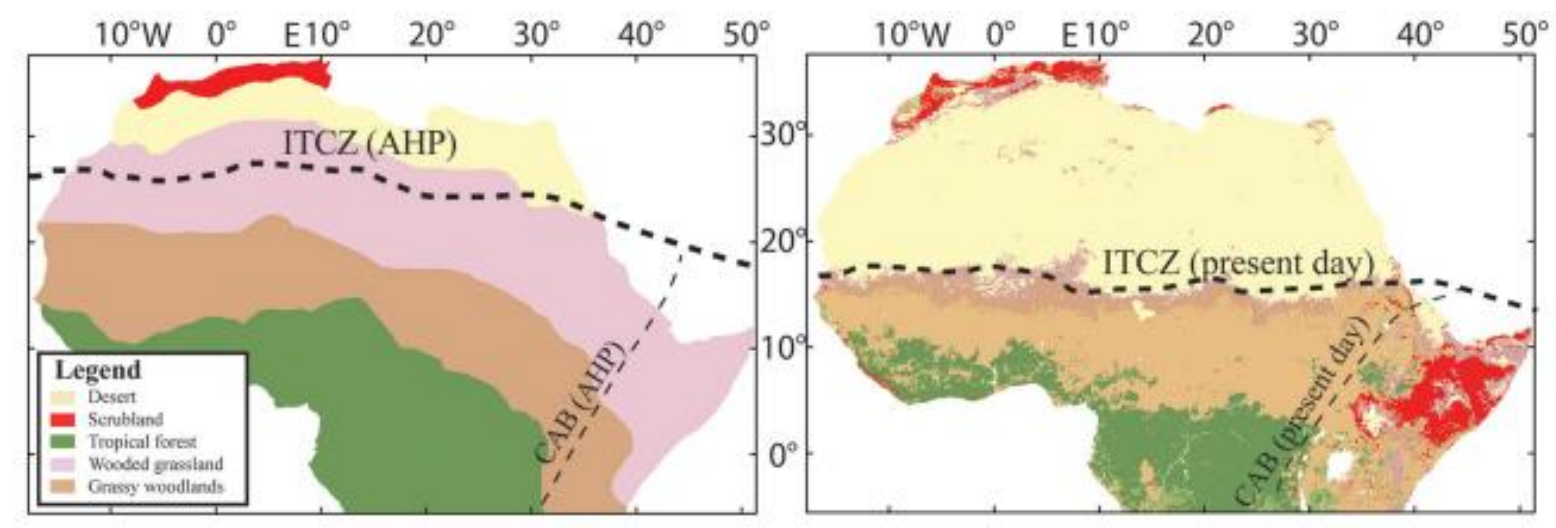

Fig. 2. Change of ITCZ from African Humid Period to present day according to Wright, (2017) with supporting studies from Larrasoaña et al., (2013); Junginger et al. (2014); Ramankutty and Foley (1999).

\section{Conclusions}

Climate and atmosphere of earth is not very stable and unchangable as we guess. Geoengineering is large-scale manipulation of the planetary environment to counteract anthropogenic (originating in human activity) climate change. To modify the atmosphere of the North Africa slowly with special care to a more humid environment by geoengineering, solar power and wind power, which are primary tools in natural atmospheric circulation, might be the main tools needed to be employed with an innovative non-electrical wind-solar power approaches.

\section{Literatures}

Anonymus 1. https://en.wikipedia.org/wiki/Desert climate

Anonymus 2. https://www.birdandhike.com/Veg/NA Deserts/ NA Deserts.htm

Anonymus 3. https://www.britannica.com/place/Arabian-Desert

Anonymus 4. https://www.freeworldmaps.net/asia/syria/map.html

Anonymus 5. https://www.mapsofworld.com/answers/world/where-are-desertslocated-in-world/

Anonymus 6. https://geology.com/records/largest-desert.shtml

Anonymus 7. https://en.wikipedia.org/wiki/List of deserts by area

Anonymus 8. www.ncdc.noaa.gov/monitoring-references/dyk/subtropical-highs

Anonymus 9. https://oceanservice.noaa.gov/facts/doldrums.html

Anonymus 10. https://en.wikipedia.org/wiki/Horse latitudes

Anonymus 11. https://www.youtube.com/watch?v=7fd03fBRsuU

Anonymus 12. https://www.e-education.psu.edu/meteo3/111 p5.html

Anonymus 13. https://www.youtube.com/watch?v=umDo7Se4QsI 
Anonymus 14. https://www.livescience.com/28493-when-sahara-desert-formed.html

Chapin, F. S., Matson, P. A., \& Vitousek, P. M. (2011). Earth's Climate System. In Principles of Terrestrial Ecosystem Ecology (pp. 23-62). Springer, New York, NY.

Junginger, A., Roller, S., Olaka, L. A., \& Trauth, M. H. (2014). The effects of solar irradiation changes on the migration of the Congo Air Boundary and water levels of paleo-Lake Suguta, Northern Kenya Rift, during the African Humid Period (15-5 ka BP). Palaeogeography, palaeoclimatology, palaeoecology, 396, 1-16.

Larrasoaña, J. C., Roberts, A. P., and Rohling, E. J. (2013). Dynamics of green Sahara periods and their role in hominin evolution. PLoS ONE 8:e76514. doi: 10.1371/journal.pone.0076514

Pan, B., Pang, H., Gao, H., Garzanti, E., Zou, Y., Liu, X., \& Jia, Y. (2016). Heavymineral analysis and provenance of Yellow River sediments around the China Loess Plateau. Journal of Asian Earth Sciences, 127, 1-11.

Ramankutty, N., \& Foley, J. A. (1999). Estimating historical changes in land cover: North American croplands from 1850 to 1992: GCTE/LUCC RESEARCH ARTICLE. Global Ecology and Biogeography, 8(5), 381-396.

Wright, D. K. (2017). Humans as agents in the termination of the African Humid Period. Frontiers in Earth Science, 5, 4. 